highly developed, especially, perhaps, in the fields of social and preventive medicine.

\section{The Objective of Medical Education}

Whatever be taught to the student, it is as well at some phase to ask ourselves coldly and critically, What is the object of undergraduate medical education? The short and incomplete answer is to turn out someone fundamentally equipped to be a practising doctor. The period of training should not be specifically directed towards the training of a general practitioner or a specialist or a public health official or an administrator, but should provide the student with a foundation for his after-career in any branch of medicine. It is his postgraduation apprenticeship and narrower studies which finally complete his early education in the branch of medicine he elects to follow, whether this be general practice or a specialized field.

The undergraduate teacher should aim at producing an educated person grounded in principle and method, able to see what the whole of medicine stands for and means, trained to observe with his hands and his senses, encouraged to think logically and critically, instructed in the use of the instruments of measurement, and equipped with a basic knowledge upon which he will continue to build for the rest of his professional life.

Are we as medical teachers doing this ? Or is teaching just a by-product of our professional life ? Do we positively examine ourselves from time to time with a critical eye, or do we complacently content ourselves with no more than getting the student over an examination hurdle ?

Are we also satisfied with the means by which a student's competence to be qualified is assessed ? Has the examination a hampering effect on what is taught and learned, and, if so, can we suggest any alternatives? Always we have to bear in mind that in many countries the manner of assessing competence and the standard are governed by law. There is, however, little doubt that experiment would show some ways in which the perpetual orthodox examinations could be advantageously modified.

Those of us who had the task of devising the programme for this Conference had to pack a great deal into the short space of a week. Many themes I should like to have heard discussed have had to be omitted. Many here might have made different choices. All of you will, I hope, by the end of this week conclude that we have made a useful beginning in tackling this most fundamental of all medical questionseducation. And if that is the conclusion, I hope that, individually and collectively, you may decide that the organizations which you represent might be asked to repeat the Conference in four or five years if it is felt that that would carry the matter further.

In the meanwhile what likelihood is there that something will be done? That those in control of medical education will really have the humility and courage to admit that all is not at its best in the best of all possible worlds, their worlds? That those who hold the shaping of the future in their hands will fashion it with vision and imagination so as to inspire the young man and woman to pursue the tasks of our great profession with a feeling of dedication to something greater than themselves? There is indeed a likelihood, otherwise so many of us would not have met here in London in the month of August. But the possibilities must be turned into probabilities and certainties, and until this happens we must possess our souls with that discontent that has so aptly been called divine.

We may aim higher than we can reach. But if we aim high we shall at least reach somewhere. Our individual and collective responsibility as a profession grows, and will grow. We cannot escape it. Medicine to-day demands much from character, intellect, and practical ability, and medicine also provides a wide variety of opportunity for all kinds of talent. But talents will be wasted or misused if the structure and content of medical education are faulty, and if medical educationists remain complacently satisfied with themselves and their methods.

\section{WHAT IS EDUCATION ?*}

\author{
BY
}

\section{Sir RICHARD LIVINGSTONE, M.A., Hon.D.Litt., Hon.LL.D.}

We have-most of us-to earn a livelihood. We find ourselves on an immense stage called the universe, occupied by strange creatures called men, and we must have enough knowledge of this scene and of its inhabitants to play our parts intelligently. And we are human beings, with a body, a mind, and also something elusive and indescribable but very real, which we call a soul or spirit-three elements which combine in our personality and which interact on each other ; and we wish to make the best of all of them, so far as our natural endowments allow. For even if there were no Great Assize before which at the end we shall be summoned to say what we have done with ourselves and our talents, the world will judge us ; and, what is more disquieting, in moments of insight and reflection we shall judge ourselves.

These three needs determine the aims of education. It should prepare us, either by a general or a vocational training, to earn our bread; it should give us some understanding of the universe and of men ; and it should help us to become fully developed human beings. Of these three aims the vocational one which concerns us as breadwinners is least likely to be overlooked; and I shall therefore say nothing about it, but concentrate on the other two aims - the making of intelligent citizens of the world and of good human beings-homines maxime homines. These two are the most important to us as men, but, since they are the less obvious and the more difficult, they may be neglected, and especially the last of them. Yet the human being is a work of art, capable of a quality and beauty of its own, quite apart from any practical purposes to which its powers are put.

\section{Science an Essential Part of Education}

We have to live in a material universe inhabited by men, and to live intelligently we must know something of both. The keys to a knowledge of the material world are commonly called (not very happily) science, and so some knowledge of it is an essential part of education. But in planning our curriculum we should distinguish between scientists, doctors, engineers, and others, who require exact knowledge of science in their occupation, and those who do not. For the needs of these two classes are not the same. The former class must have specialist knowledge of the sciences which they require for their life's work. The need of the others is different. It is less important to teach them chemistry or physics or biology than to give them an idea of the meaning of the changes that came in human affairs about 600 8.c., when some Greeks realized that there was more in the universe than the senses could perceive, and began looking beneath the surface of phenomena to underlying realities and laws, and science was born: and, again, when in a later day other men conceived that through such knowledge nature could be controlled as well as understood, and science gave birth to her child, technology.

To realize the meaning of science, her powers and procedures, the instruments of observation and experiment by which she works-that is more important than teaching individual sciences to pupils who are not going to specialize in science-it is, of course, only of them that I am speaking. By all means add to this essential core as much as

*An address given in the plenary session of the First World Conference on Medical Education on August 24. 
time permits. But I can see no use in being taught, as I was, the elements of chemistry and physics without ever having an idea of their meaning and use, or any conception of the fascinating truth that you can transform things by analysing them into their constituent elements. The teaching I had did not make me less of a stranger in the material universe than I was before. It only gave me a transitory knowledge of some isolated facts in which I saw no meaning.

Science, then, though in different forms, must have a place in all education, for the material universe is the stage on which the human drama is played. We say, no doubt, that man is not the centre of the universe, but, however true that may be, everyone continues to act much as if he was; if we did not think our activities of great importance we should cease to take them seriously. But the drama is human and the actors are men, and the actor is more important and interesting than the stage. His fortunes are, in practice if not in theory, the fortunes of our world, and apart from them it would have lost any meaning. Man is the source of ideas and ideals, the deviser of progress and its instrument, the maker of that rich and ingenious structure which we call civilization. As Shakespeare put it, "What a piece of work is a man. How noble in reason! how infinite in faculty! ... in action how like an angel! in apprehension how like a god! the beauty of the world! the paragon of animals!" That is man in his better moments ; he has other moments too. Anyhow, in himself he is a fascinating study, and without some study of him we shall not live our lives with intelligence, interest, or, in any but the narrowest sense, success. That is why Dr. Conant, himself a distinguished chemist, said that "in terms of general education, poetry and philosophy are of vastly more importance than science" ; so history and literature must enter into any education; for they are our chief records of man and his ways.

\section{Place of History and Literature}

In history we see his slow ascent from savagery to a complicated civilization, his experiments, mistakes, failures and successes in the climb, the states he has founded, static or progressive, transitory or stable, the forces that have brought him on or kept him back, the virtues that have sustained his efforts, the vices that have brought them to nothing. History is a clinical study of man in society. Literature is more personal. Here we meet man in his intimate moments, talking to the world, but really to himself, so that in literature are recorded all the thoughts, feelings, passions, visions, and dreams that have ever passed through the human mind; and some of the visions play a great part in human progress. In one way literature is less instructive than history, because history has to do with facts, and poetry with visions ; in another way more so, just because it is more intimate, more personal. We meet human nature in undress, we meet ourselves, but also we are taken beyond ourselves to an exceeding high mountain and shown all the kingdom of man and the glory of it. Religion first, but close after it poetry, reveal powers and qualities in man which otherwise we should not know. Lifted on the shoulders of genius, we catch a glimpse of undivined worlds which are within the reach of the human spirit.

\section{The Right Aim}

But, you may reasonably ask, is this the way in which literature and history are taught in schools, or even in universities; is this the light in which they are presented to the pupil; and do not many people study them without any clear idea what they are about? I will not answer these delicate questions, but they remind us of an important fact. It has been said that it does not matter what subject you teach a pupil, if you teach it well. I would add (though neither of these epigrams is quite true) that it is

${ }^{1}$ Education in a Divided World, p. 126. no use teaching anything if you teach it badly. And not only must a subject be taught well it must be taught appropriately. I argued earlier that it is a mistake to teach science to an arts specialist in exactly the same way as you would teach it to someone whose main study it is. I do not think that this mistake is now often made in teaching science to those who will never specialize in it. But it is, I fancy, sometimes made in teaching literature and history to scientists. The right aim in teaching these subjects to those whose work and interests are in science is less to instruct them than to awake the mind, to make the pupil feel the interest of literature and history, even though his detailed knowledge of them may be small. I would rather that a boy had read one dialogue of Plato, one canto of Dante, one play of Shakespeare or Racine with real enjoyment, and with a keen sense of its greatness, than that he should be hurried through masses of literature which he neither understands nor enjoys nor absorbs. If he is interested, he is likely to pursue the study further in his leisure ; and he will at least have become aware that there are more things in heaven and earth than are dreamt of in his specialism. By all means add to this stimulus as much knowledge, as wide a survey, of history and literature as you have time for: but without the stimulus these are vain. General culture is designed, as Whitehead said, "to foster an activity of mind."

\section{Four Points}

So far I have been talking about the introduction to the kingdoms of nature and of man-a preparation to feeling at home and living intelligently on the stage where we find ourselves. But we also need some instruction about how to behave there, and I shall mention briefly four points of good behaviour. One point is to learn how to express ourselves intelligibly to others. A second point is to know how to read a book, noting exactly what it says. A third point is to think clearly and logically. John Morley said that an educated man knew when a thing was proved and that an uneducated man did not know; and this saying, though not an exhaustive account of education, calls attention to an essential element in it.

Logical thinking is one way to truth, but it is not the only road, nor is it a complete one, and so I should add to my proposed code of behaviour a fourth item-the insight that comes from sensitiveness-to supplement and correct the knowledge which comes from hard thinking. This is often neglected in our education. The sensitive person with an undisciplined mind is a danger; so, less obviously, is the mere intellectual. $\mathrm{He}$ is not likely to be good at what has been described as the sacred duty of getting under other people's skins-especially the skins of people unlike himself. Some human beings are born with the sensitiveness that makes this easy and habitual. But it is a gift that can be trained, and the best training in it is given by two subjects that find a place in any curriculum-history and literature, especially literature, where the reader enters into the mood of the writer, the atmosphere of the poem, the temperament of the character described. Take for instance Shakespeare's Othello. Except for the pleasure which the rich language gives, one might just as well not read it if one does not for the moment creep under the skin of the Moor, of Desdemona-yes, and of Iago-and feel as they feel in the play. Of course literature has the power of absorbing us in bad, as well as good, moods and atmospheres; that is the reason why Plato thought it dangerous. But a training in sensibility and the insights which sensibility gives is essential. For knowledge is not merely the collection of facts; it depends on imagination as well as on reason.

\section{An Overruling Principle}

So far I have suggested that the aim of education is at least to introduce us to the worlds of Nature and of Man, and to train the powers of reason and imagination and the art of expression needed for effective behaviour in them. 
But that is not enough. It would be possible to have all these and yet be without that overruling principle which we call a philosophy of life; a force to steady the purpose and give it direction, to concentrate the abilities and bring them to bear, to recall and revive the flagging energies; a force which is

When empty terrors overawe

Victory and law

From vain temptations doth set free

And calm the weary strife of frail humanity.

An education is incomplete unless it leaves people with what I have called a philosophy of life, and never was this more needed than in our age of uncertainty. But the very conditions which make it desirable make it difficult. Order is not easily visible in chaos, nor a clear voice audible in a confusion of tongues. The Christian no doubt has firm beliefs and clear standards, and my own conviction is that Christianity will become again the philosophy of the Western world; but that day is not yet. Meanwhile can we find an interim philosophy which can be imparted through education and which is sufficiently powerful to dominate men's minds and hearts, sufficiently convincing to win a general assent? It is not easy to see one. What philosophy of life - to take an obvious instance-can the Western and the Russian blocs share? There is only one creed which men in every continent agree to repeat: "I believe in Science and in its child Technology." That is a startingpoint ; it is something. But it only covers a limited area of conduct, and it does not profess to answer the most important questions about life and human nature. You cannot call it a philosophy. A principle of wider range is needed.

\section{Philesophy of the First-rate}

There is a philosophy which gives standards of value and judgment that apply to all spheres and activities of human life. It is a very simple one, and no one would reject it. I would call it the Philosophy of the First-rate. Ask a doctor or a surgeon if he is ignorant of or indifferent to the best methods in his profession. Would he answer yes? Or would he consider that there are no differences of quality in art, literature, music, architecture, and that it does not matter whether a picture or a sonata or a play or a building is first-rate or third-rate? Or, taking the inquiry into a still more important province, do we think that when we apply the words good or bad to human character and conduct we are drawing meaningless and unimportant distinctions? In all fields of life all people, whatever their creed or race, admit what I called the philosophy of the first-rate. I have already quoted John Morley's saying that an educated man knew when a thing was proved and that an uneducated man did not know. I would prefer to say that an educated man knows, and an uneducated man does not know, what is first-rate, and that the besteducated man is he who knows the first-rate in the most important human activities.

The supremacy of the first-rate is a self-evident axiom. But it is sometimes an unrealized axiom. We are like the slave in the Meno, who had the principles of geometry latent in his mind, but never recognized them till Socrates played the midwife and brought his subconscious knowledge to the birth. For our purpose education must be the midwife-the metaphor suggests one of the most fruitful and fundamental conceptions in that field-and bring to birth this philosophy of the first-rate, which is so fruitful and which no human being would disown.

But how do you know the first-rate? How do you recognize it in practice? There is only one way of getting to know it-by seeing it ; and that is the way in which it can be taught. I imagine that the medical student will learn more by seeing a great surgeon at work or by going round the wards with a great doctor than all the textbooks in the world can teach him. It is the same in anything. People learn what is first-rate by contact with it. You learn what is great music by hearing it, what is great architecture by seeing it. You learn first-rate business methods by working in a first-rate business firm. It is the same everywhere. You acquire a good taste in wine by drinking good wine, in good cigars by smoking them.

In cigars and wine, if we have the money, in art and music, even if we have not, it is easy to come across the first-rate. But where do we find it in character and life? It is at hand; in the great religions, and the great moral systems, but also in literature and history, though here the pure gold runs in veins amid much worthless matter. Make, for instance, a list of the good men and women in Shakespeare's plays, and what a company of noble characters you will assemble. Here, and throughout the literatures and the history of every country, archetypes of excellence are present for the looking. These are the great sources on which we can draw, and here is one reason why an education which ignores the humanities is disastrously incomplete. I do not of course suggest that the study of history and literature is only the study of human ideals, conduct, and character. Obviously these subjects have many other aspects. But it is with this aspect of them that we are concerned at the moment. Therefore, for our particular purpose, history and literature must be read from this angle and with this aim in view. Unfortunately this is often ignored in the teaching of history and even of literature. Their teachers have usually been trained as experts by experts, and are interested in those other aspects of the subject with which universities concern themselves, but which, necessary and important as they are, are of no use for our particular purpose. For that, history and literature must be treated as mirrors of human character, and indeed as moral philosophy in the concrete.

But, you may ask, how do you know what is first-rate in literature and art, and still more in human character? As Browning puts it,

Ten men love what I hate,

Shun what I follow, slight what I receive,

Ten, who in ears and eyes

Match me: we all surmise

They this thing, and I that: whom shall my soul believe ?

That is a plausible question, but more embarrassing in dialectic than in fact. There is no real doubt that Homer and Shakespeare are great poets, Bach and Beethoven great musicians, Plato and Kant great thinkers, Newton and Faraday great men of science. Even in the more uncertain field of character and conduct no one is likely to doubt that in St. Francis or the Buddha, in Lincoln and Masaryk, we see the first-rate. We are safe in accepting the judgment of time ; it is rarely reversed on appeal.

To repeat, an education which leaves us without a philosophy of life is as incomplete as one which leaves us unable to think or to express our thoughts. And never was a philosophy as necessary as in an age of divided purposes and paralysing doubts about ultimate ends. Our civilization is fluid, its future form still to seek and make. At present it is a curate's egg civilization-some of it excellent, some of it fourth-rate. If you question this criticism, look at our cheap daily papers. Yet ours is an age of great vitality, of unlimited powers and possibilities, too often frittered away or misused. We have the materials of a great civilization: all that is needed is to stamp it with the print of excellence. The more reason that our education should train our youth to desire, recognize, and pursue the firstrate.

According to a press report, a public opinion poll organized by the psychology department of Victoria University College, Wellington, New Zealand, showed that the social status of doctors was put higher than that of the other professions and occupations. After the doctors came lawyers, company directors, business managers, nonconformist clergy, accountants, chiefs of Civil Service departments, works managers, farmers, and teachers, in that order. 